\section{CITAÇÃO}

Fernandes, P.A. (2020)

A Ciência é a única arma,

Rev. Ciência Elem., V8(02):017.

doi.org/10.24927/rce2020.017

\section{EDITOR}

José Ferreira Gomes,

Universidade do Porto

\section{PUBLICADO EM}

30 de junho de 2020

\section{COPYRIGHT}

(C) Casa das Ciências 2020.

Este artigo é de acesso livre, distribuído sob licença Creative

Commons com a designação

CC-BY-NC-SA 4.0, que permite

a utilização e a partilha para fins não comerciais, desde que citado o autor e a fonte original do artigo.

\section{rce.casadasciencias.org}

\title{
A Ciência é a única arma
}

A humanidade estava já desabituada de conviver com as epidemias, as nossas velhas companheiras tão antigas quanto a civilização humana. As pandemias são de facto um fruto da revolução neolítica; a nossa capacidade de dominar a agricultura e a pecuária, a consequente sedentarização e a aglomeração das populações em densas aldeias, vilas e cidades, bem como os intercâmbios comerciais que se seguiram, foram o fator que fez nascer as pandemias. Uma doença infeciosa nunca se disseminaria por grandes regiões geográficas tendo como veículo pequenos grupos de caçadores-recoletores dispersos, facto sustentado pela total falta de evidência arqueológica sobre pandemias nesse período. Não deixa de ser curioso pensar que foi a civilização que fez nascer as pandemias, que devastaram continentes, dizimaram civilizações, decidiram guerras e derrubaram impérios no passado, mas que a ciência, um dos apogeus máximos da civilização, tem sido a ferramenta que melhor tem conseguido controlar, dominar, e até erradicar muitas delas. A ciência é a nossa tábua de salvação para lidar com as pandemias.

Os extraordinários progressos e sucessos da ciência conseguiram controlar muitos dos potenciais surtos epidémicos nos tempos modernos. A pandemia mais importante $\mathrm{e}$ mortífera da atualidade, a SIDA, não nos parece tão assustadora como a COVID-19 pois dispomos de formas simples e extremamente eficazes de prevenir o contágio.

De todas as técnicas científicas, a que porventura mais se destacou para nos libertar de pandemias foi a vacinação. A vacinação libertou-nos definitivamente da varíola e limitou imenso as infeções por sarampo, tétano ou poliomielite, entre outras doenças. De facto, a OMS (Organização Mundial de Saúde) estima que pelo menos dez milhões de pessoas tenham sido salvas pela vacinação na última década. Surpreendentemente, e apesar do seu extraordinário sucesso, a vacinação é hoje alvo de um movimento de contestação injustificável que se serve de falsos argumentos e falsa ciência para pôr em causa os inegáveis benefícios das campanhas de vacinação.

A maioria das pessoas percebeu já a gravidade da pandemia COVID-19 e as consequências que teria tido, não fossem postas em prática medidas de confinamento extraordinárias. Também já percebeu que a ciência é a nossa esperança e a nossa tábua de salvação, seja através das tecnologias hospitalares de tratamento, das tecnologias de prevenção do contágio (onde os também injustamente criticados "químicos", usados massivamente como desinfetantes, têm salvo imensas vidas e retardado muito a pandemia), seja através do desenvolvimento de fármacos e vacinas. De facto, os raros países que têm recusado seguir uma gestão científica da pandemia são hoje os mais fustigados por ela.

Neste contexto, entendemos ser relevante lançar uma edição especial da Revista de 
Ciência Elementar dedicada à COVID-19. Coligimos uma coletânea de artigos que se debruçam sobre diversos aspetos científicos das epidemias, que são genéricos e transversais, fazendo sempre uma ligação entre a ciência das pandemias e a atual COVID-19. Esta coletânea aborda aspetos históricos das pandemias, aspetos (bio)químicos sobre desinfeção e sobre desenvolvimento de novos fármacos, aspetos farmacológicos sobre o tratamento de alguns dos efeitos da doença, aspetos matemáticos sobre a modelação da evolução da pandemia e até alguns aspetos artísticos da ciência.

Temos esperança na ciência, e esperança de em breve lançar uma edição especial dedicada a uma análise retrospetiva do papel da ciência na erradicação da pandemia por COVID-19!

\section{Pedro A. Fernandes}

Editor convidado 